Article

\title{
Variations of Climate-Growth Response of Major Conifers at Upper Distributional Limits in Shika Snow Mountain, Northwestern Yunnan Plateau, China
}

\author{
Yun Zhang, Dingcai Yin, Mei Sun, Hang Wang, Kun Tian, Derong Xiao and Weiguo Zhang * \\ National Plateau Wetlands Research Center, Southwest Forestry University, Kunming 650224, China; \\ zhangyuncool@163.com (Y.Z.); yindingcai@126.com (D.Y.); sm0510215@163.com (M.S.); \\ hwang17@163.com (H.W.); tlkunp@126.com (K.T.); xiaoderong1@163.com (D.X.) \\ * Correspondence: zhangweiguo61@163.com; Tel.: +86-871-386-4277; Fax: +86-871-386-3477
}

Received: 11 July 2017; Accepted: 27 September 2017; Published: 4 October 2017

\begin{abstract}
Improved understanding of climate-growth relationships of multiple species is fundamental to understanding and predicting the response of forest growth to future climate change. Forests are mainly composed of conifers in Northwestern Yunnan Plateau, but variations of growth response to climate conditions among the species are not well understood. To detect the growth response of multiple species to climate change, we developed residual chronologies of four major conifers, i.e., George's fir (Abies georgei Orr), Likiang spruce (Picea likiangensis (Franch.) E.Pritz.), Gaoshan pine (Pinus densata Mast.) and Chinese larch (Larix potaninii Batalin) at the upper distributional limits in Shika Snow Mountain. Using the dendroclimatology method, we analyzed correlations between the residual chronologies and climate variables. The results showed that conifer radial growth was influenced by both temperature and precipitation in Shika Snow Mountain. Previous November temperature, previous July temperature, and current May precipitation were the common climatic factors that had consistent influences on radial growth of the four species. Temperature in the previous post-growing season (September-October) and moisture conditions in the current growing season (June-August) were the common climatic factors that had divergent impacts on the radial growth of the four species. Based on the predictions of climate models and our understanding of the growth response of four species to climate variables, we may understand the growth response to climate change at the species level. It is difficult to predict future forest growth in the study area, since future climate change might cause both increases and decreases for the four species and indirect effects of climate change on forests should be considered.
\end{abstract}

Keywords: Hengduan Mountains; dendrochronology; climatic response; redundancy analysis

\section{Introduction}

The effects of global change on the human living environment and Earth's ecosystems have caused concern. Climate change, as an important component of global change, has a great influence on the structure and function of terrestrial ecosystems, particularly for forest ecosystems [1,2]. How forest growth will respond to climate change has become an important scientific issue [3]. Dendroclimatology, as a traditional method of analyzing historical climatic conditions, plays an important role in studying the response of tree growth to climate change [4]. Analyzing the relationship between radial growth of the main tree species and climatic variables can help to reveal key climatic factors influencing tree growth and forest growth [5-7].

The response of forest growth to future climate change can only be evaluated if species-specific responses are well understood, since forests are composed of different species and these species are 
likely to show variations in response to climate due to their different physiological adaptations and growth strategies [8,9]. Additionally, species differences in mountainous areas have been suggested to be more important in adaptation to change than site differences [10-12]. The results of published studies have revealed the complexity of species-dependent growth response to climate and suggested that precise predictions of the effects of climate change on mountainous forests require a more thorough understanding of the relationships between climate factors and multiple-species growth $[7,10]$.

Trees growing in the elevational limits are more sensitive to climate change, since they are under physiological stress [13-16]. Radial growth of trees at their upper distributional limits generally reflect temperature variations. Low temperature has been suggested to be the limiting factor controlling tree growth [17]. However, because of the complexity of plant physiological reactions and processes, this rule is not applicable for every tree species. The response of radial growth of multiple tree species to climate change can be different in subalpine forests [18-20].

Northwestern (NW) Yunnan Plateau, located in the southeastern edge of the Tibetan Plateau, belongs to a region sensitive to global climate change [21]. Several tree species form the upper treeline on different snow mountains in the region, and this makes the mountains perfect sites for dendrochronological study. At present, there are several studies from this region that have used tree-rings to reconstruct the climate [22-27]. Additionally, tree growth response to climate change has been studied in two typical nearby sites, i.e., Yulong Snow Mountain and Potatso National Park; the results showed that tree growth was affected by both temperature and precipitation [28,29]. Previous studies have shown tree growth to be sensitive to climatic variability, but sampled species were mainly limited to fir and spruce [22-24,26] and sampled sites were concentrated on Yulong and Baima Snow Mountains [22,26]. Shika Snow Mountain is another typical subalpine mountain in NW Yunnan Plateau, but few dendroclimatological studies have been carried out there. The increase of sampling sites and the expansion of tree species can improve the dendroclimatological knowledge in the region.

The aim of this study was to elucidate the main climatic factors influencing tree growth in Northwest Yunnan Plateau by studying the growth response of George's fir (Abies georgei Orr), Likiang spruce (Picea likiangensis (Franch.) E.Pritz.), Gaoshan pine (Pinus densata Mast.) and Chinese larch (Larix potaninii Batalin) to climate conditions at their upper distributional limits in Shika Snow Mountain. The selected four species were major conifers in Northwest Yunnan Plateau and typically formed pure forests, respectively. Based on our results and the predicted climate change conditions, we further discuss tree growth under the future climate. We hypothesized that temperature would be a limiting factor affecting the radial growth of the four species due to low temperatures at the upper distributional limits, and that variation of the growth response to climate depended on the respective biological characteristics of the tree species. More specifically, we studied (1) relationships between the residual chronologies of the four species and climatic factors by using response function analysis (RFA) and redundancy analysis (RDA), and (2) compared variations of the growth response to climate among the four species.

\section{Materials and Methods}

\subsection{Study Area}

Conifer forests with different dominant canopy species are major forest types in Northwest Yunnan Plateau; each forest type possesses a unique assemblage of sub-canopy trees and shrubs, and the vertical structure is relatively simple. Fir forests are limited to $3200-4100 \mathrm{~m}$ above sea level (a.s.l.) with Rhododendron species as major subcanopy trees. Spruce forests are distributed from 3100 to 3800 $\mathrm{m}$ a.s.l. with Quercus species as major subcanopy trees and Lonicera species as major shrubs. Pine forests range from 2700 to $3700 \mathrm{~m}$ a.s.l. with Rhododendron species as major shrubs. Larch forests are located between 3100 and $4000 \mathrm{~m}$ a.s.l. with fir as subcanopy trees.

Shika Snow Mountain, which has rich species diversity, is located in the center of the Hengduan Mountains, Northwest Yunnan Plateau, China (Figure 1). It is characterized by a vertical zonation of 
forest ecosystems with little disturbance (mainly fire with low frequency and intensity). P. likiangensis, P. densata, A. georgei, and L. potaninii are the main tree species in the area. A. georgei is a shade-tolerant and shallow-rooted species, which can adapt to cool and cold climate, and which is distributed from $3200 \mathrm{~m}$ a.s.l. to $4100 \mathrm{~m}$ a.s.l. P. likiangensis is a shade-tolerant and shallow-rooted specie that is distributed from $3100 \mathrm{~m}$ a.s.l. to $3810 \mathrm{~m}$ a.s.l. P. densata is a deep rooted, shade-intolerant species, which is tolerant of dry and poor soil and which is distributed from $2700 \mathrm{~m}$ a.s.l. to $3700 \mathrm{~m}$ a.s.l. L. potaninii is a shade-intolerant species with an underdeveloped main root; it is toleratn to poor soil and is distributed from $2700 \mathrm{~m}$ a.s.l. to $3900 \mathrm{~m}$ a.s.l.

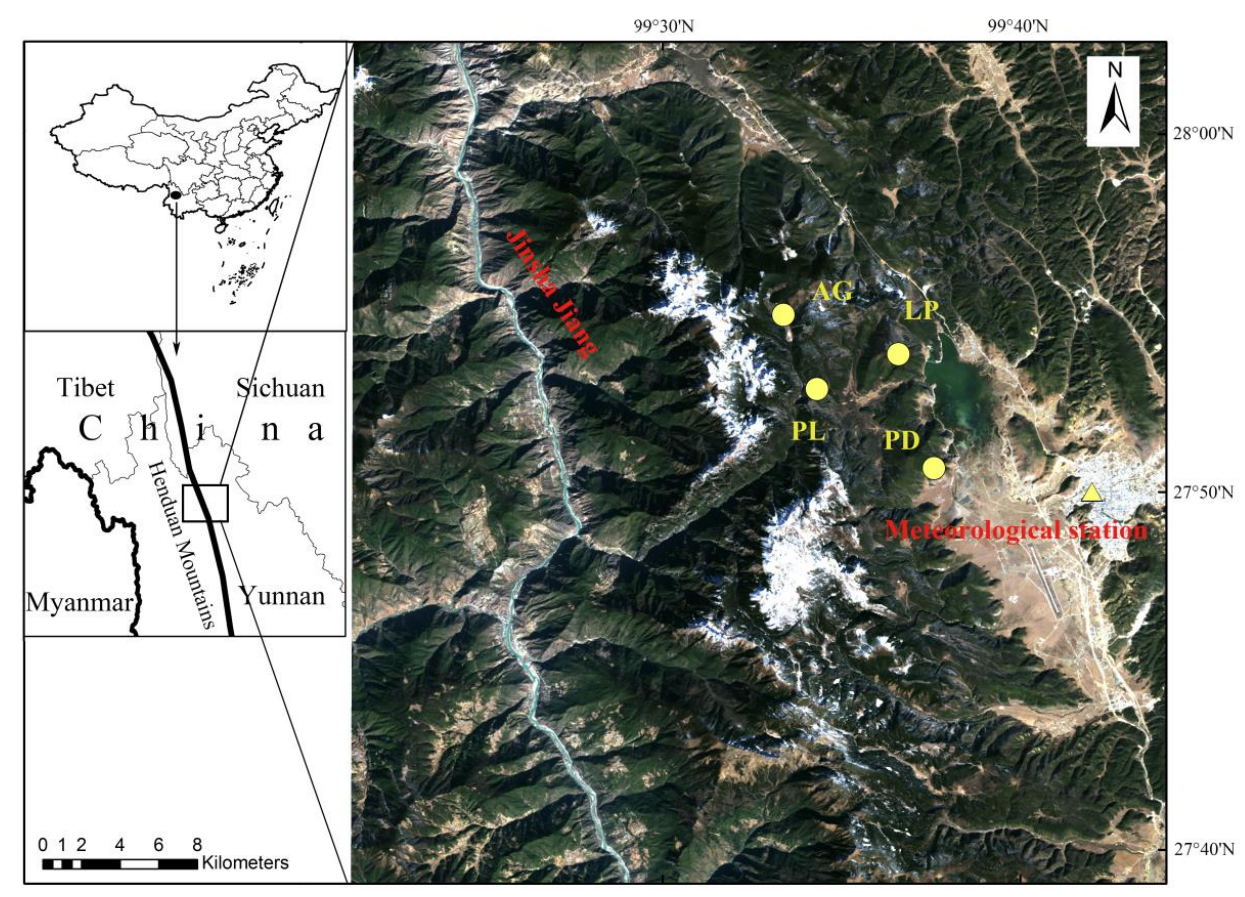

Figure 1. Location of the sampling sites and the meteorological stations nearby. AG: Abies georgei site, LP: Larix potaninii site, PL: Picea likiangensis site, PD: Pinus densata site.

The climate in this area is strongly influenced by South Asian summer monsoons and is characterized by maximum rainfall during the summer months (June-September), whereas winters are generally dry. Shangri-La meteorological station $(3276.7 \mathrm{~m})$ is the station closest to the sampling sites; climate observations have been available from this station from 1960 onwards. According to the climatic record from Shangri-La meteorological station for the period 1960-2011, mean annual temperature is $5.9^{\circ} \mathrm{C}$, July is the hottest month with an average temperature of $13.6^{\circ} \mathrm{C}$, and January is the coldest month with an average temperature of $-3.0^{\circ} \mathrm{C}$. The mean annual precipitation is $634 \mathrm{~mm}$. The precipitation in the summer season accounts for $73 \%$ of the total annual precipitation (Figure 2a). From 1960-2011, temperature showed a significant increasing trend (Figure 2b), while precipitation increased only slightly (Figure 2c).

\subsection{Sampling and Chronology Development}

We collected tree ring materials from four stands at the upper distributional limits of the four species at Shika Snow Mountain. In total, 162 increment cores from 83 trees were sampled at four sites (for more stand information please see Table 1). At each site, we sampled dominant trees without insect damage and fire scar at breast height (approximately $1.3 \mathrm{~m}$ ) with an increment borer. Two (or one) cores were taken per tree from opposite directions, which were parallel to the contour line. In order to ensure the consistency of the microclimate, the elevation variation was controlled within $10 \mathrm{~m}$ at each site. 

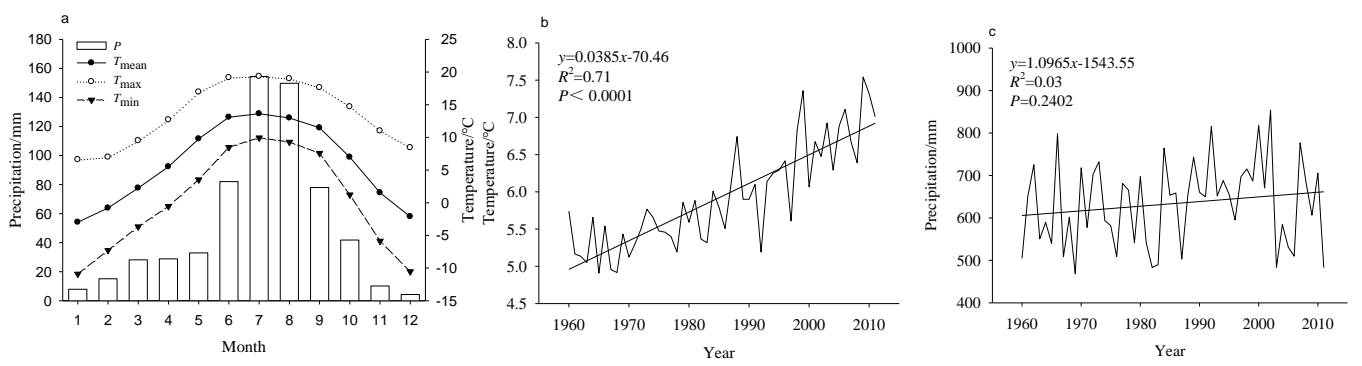

Figure 2. Climate data from the Shangri-La meteorological station (1960-2011). $T_{\max }$ : monthly mean maximum temperature; $T_{\text {mean }}$ : monthly mean temperature; $T_{\min }$ : monthly mean minimum temperature; P: monthly total precipitation.

Table 1. Descriptions of the sampling sites.

\begin{tabular}{cccccccc}
\hline Tree Species & Latitude & Longitude & $\begin{array}{c}\text { Number of } \\
\text { Trees/Cores }\end{array}$ & Elevation & $\begin{array}{c}\text { Slope } \\
\text { Aspect }\end{array}$ & Slope $\left(^{\circ}\right)$ & Soil Type \\
\hline Picea likiangensis & $27^{\circ} 52^{\prime} 52.20^{\prime \prime} \mathrm{N}$ & $99^{\circ} 34^{\prime} 18.48^{\prime \prime} \mathrm{E}$ & $14 / 26$ & $3618 \mathrm{~m}$ & $\mathrm{E}$ & 15 & $\mathrm{Clay}$ \\
Pinus densata & $27^{\circ} 50^{\prime} 39.84^{\prime \prime} \mathrm{N}$ & $99^{\circ} 37^{\prime} 34.72^{\prime \prime} \mathrm{E}$ & $34 / 68$ & $3625 \mathrm{~m}$ & $\mathrm{~W}$ & 13 & Sand \\
Abies georgei & $27^{\circ} 54^{\prime} 56.70^{\prime \prime} \mathrm{N}$ & $9^{\circ} 33^{\prime} 22.32^{\prime \prime} \mathrm{E}$ & $19 / 36$ & $4074 \mathrm{~m}$ & $\mathrm{E}$ & 10 & $\mathrm{Clay}$ \\
Larix potaninii & $27^{\circ} 53^{\prime} 50.68^{\prime \prime} \mathrm{N}$ & $99^{\circ} 36^{\prime} 35.24^{\prime \prime} \mathrm{E}$ & $16 / 32$ & $3819 \mathrm{~m}$ & $\mathrm{~W}$ & 15 & Sand \\
\hline
\end{tabular}

The samples were pretreated according to the method described by Stokes and Smiley [30] after being brought back to the laboratory. The surface of a core was burnished with sandpaper until the surface was smooth enough to recognize the tree ring. The cores were placed under the microscope for dating work, and dated cores were scanned using an EPSON scanner (Expression 11000XL, Seiko Epson Corporation, Nagano county, Suwa City, Japan) with parameters set to image type 24-bit full color and a resolution of $3200 \mathrm{dpi}$. The ring widths were measured on the scanned images in CDendro and CooRecorder ver. 7.3 program [31] with a resolution of $0.001 \mathrm{~mm}$, and statistical tests were applied using the software package COFECHA [32] to validate the data quality. The cores with low correlation between the tree ring sequences and the main sequences were excluded and, finally, 145 cores (80 trees) were kept in the main sequence (Table 2). Each series was standardized to remove the biological growth trend (age-size) as well as other low-frequency variations due to stand dynamics [33], by using a cubic smoothing spline with $67 \%$ of the series length. We also used autoregressive (AR) modeling on each standardized series to remove temporal autocorrelation and enhance the common signal. The residual tree-ring series were averaged using residuals from AR modeling of the standardized measurement series, and the residual chronologies of the four species (RES, Figure 3) were used to analyze the climate-growth relationships. All procedures were conducted using the program ARSTAN [34].

Table 2. Statistics of residual chronologies and common interval analysis.

\begin{tabular}{lcccc}
\hline \multicolumn{1}{c}{ Chronology } & P. likiangensis & A. georgei & P. densata & L. potaninii \\
\hline Chronology length & $1898-2014$ & $1517-2014$ & $1813-2015$ & $1916-2015$ \\
Mean ring width (mm) & 1.95 & 0.95 & 0.95 & 1.73 \\
Mean sensitivity & 0.13 & 0.15 & 0.16 & 0.22 \\
1st order autocorrelation & -0.15 & 0.01 & -0.01 & 0.19 \\
\hline Common interval analysis (1960-2011) & & & & \\
\hline Number of trees/cores & $12 / 22$ & $19 / 34$ & $33 / 59$ & $16 / 30$ \\
Variance expressed by the first & 38.76 & 40.58 & 42.94 & 47.31 \\
principal factor (\%) & 0.90 & 0.95 & 0.97 & 0.95 \\
Expressed population signal & 0.33 & 0.37 & 0.41 & 0.43 \\
Correlation among the trees & & &
\end{tabular}




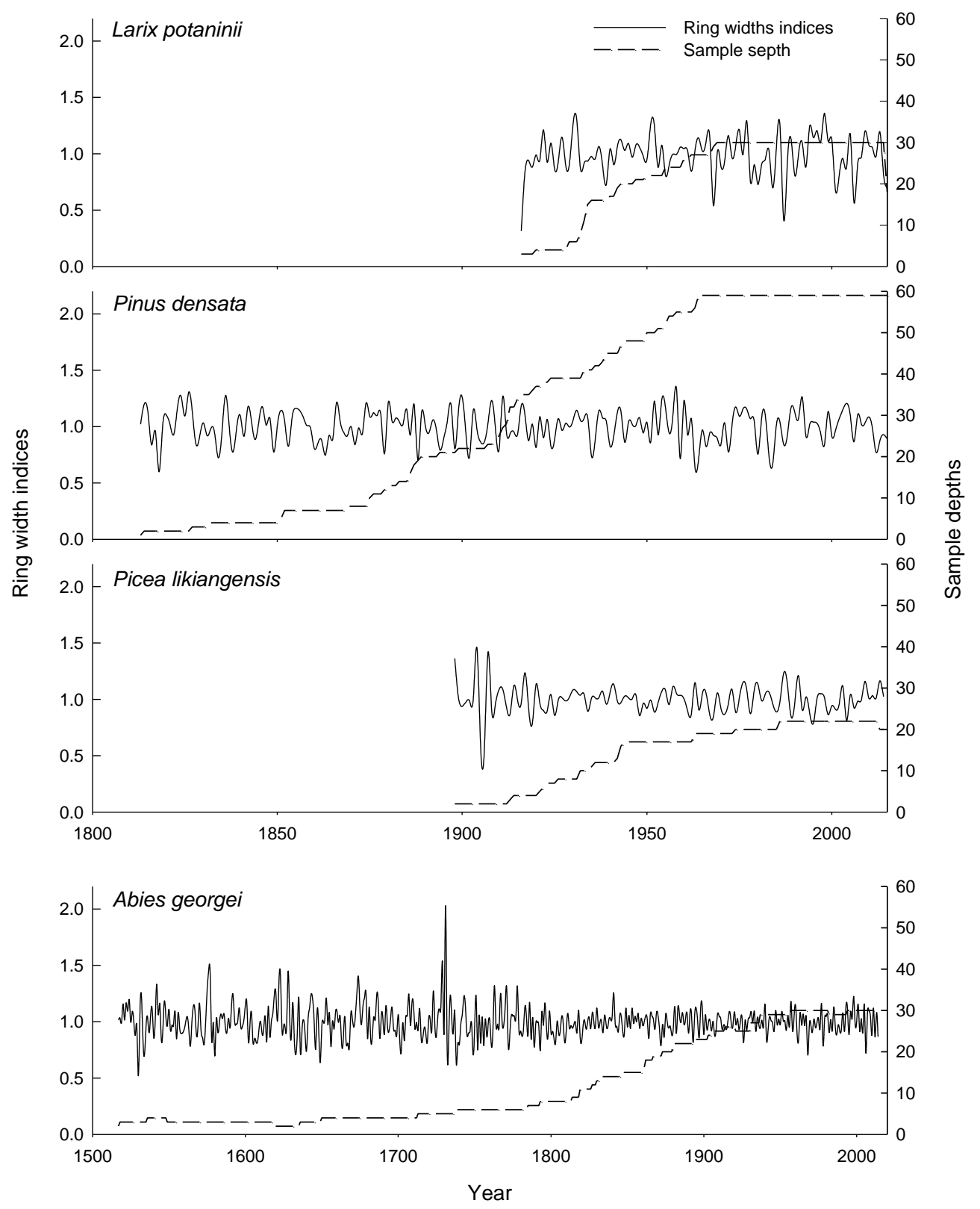

Figure 3. Residual tree-ring chronology (solid line) and sample size (dotted line).

\subsection{Climate Data}

We used climate data for the period 1960-2011 (common interval of the four species) from Shangri-La meteorological station. For climate analyses, monthly mean temperature $\left(T_{\text {mean }}\right)$ and monthly total precipitation from July of the previous year to October of the current year, and the $T_{\text {mean }}$ and the total precipitation of the post-growing season (September-October) of the previous year, the early growing season (April-May), the growing season (June-August), and the post-growing season of the current year were selected. There was no heterogeneity in the climate data when tested by the Mann-Kendall method [35]. Therefore, we assumed that the observed record of the Shangri-La meteorological station reflects the natural climate change of the study area, and we used the meteorological data for the climate-growth relationship analysis. 


\subsection{Statistic Analyses}

We used RFA to analyze relationships between the residual chronologies of the four species and climatic factors by using DendroClim2002 program [36]. The response function is a linear multiple regression technique that uses the principal components of monthly climatic variables to estimate tree-ring growth and is usually applied in climate-growth analyses [37]. We also used a 32-year moving window with forward evolutionary intervals to study the temporal stability of climate-growth relationships, carried out with the Evolutionary and Moving Response and Correlation module in DendroClim2002. Redundancy analysis (RDA) is also useful for analyzing and verifying the relationship between radial growth and climatic factors. RDA is a multivariate "direct" gradient analysis and its ordination axes are constrained to represent linear combinations of supplied environmental variables [38], the use of RDA is appropriate when short environmental gradients are covered [39]. In the correlation matrix of RDA, the four residual chronologies were considered as response variables, the years were considered as samples, and climate variables were considered as explanatory variables and were transformed into ordination axes. Significant climatic variables $(p<0.05)$ were selected after a forward selection using a Monte Carlo permutation test based on 999 random permutations. RDA was conducted by using the program CANOCO4.5 [40].

\section{Results}

\subsection{Characteristics of the Tree-Ring Width Chronologies}

A. georgei had the longest chronology among the four species, while L. potaninii chronology was the shortest, the length of the chronologies for P. likiangensis and P. densata were 116 and 202 years, respectively. The two shade-intolerant species (L. potaninii and P. densata) generally had higher values in statistical indices, such as mean sensitivity (MS), the first principal component (PC1), the expressed population signal (EPS), and correlation among the trees, suggesting that these two species had higher quality in chronologies as compared to the two shade-tolerant species $[4,41,42]$. EPS values of all four species were above 0.85 , indicating a strong common signal among the species and suitability of constructed chronologies for dendrochronological study [41].

\subsection{Climate-Growth Relationships}

RFA indicated that the radial growth was mainly influenced by temperature conditions and precipitation played a minor role on the radial growth in the area (Figure 4), but the four species responded differently to climatic factors. The radial growth of $P$. likiangensis showed a significant and positive correlation with $T_{\text {mean }}$ of the current July. Precipitation inhibited P. likiangensis growth, by showing a negative correlation with precipitation of the previous August and the current early growing season (April-May) (Figure 4a). The radial growth of A. georgei was significantly and positively correlated with $T_{\text {mean }}$ of the previous November and $T_{\text {mean }}$ of the current growing season (June-August), $T_{\text {mean }}$ of the previous September negatively influenced its growth (Figure $4 \mathrm{~b}$ ). For P. densata, warm temperatures in the previous post-growing season and November, as well as the current early growing season, had a positive impact on the radial growth, and hot July inhibited its growth (Figure 4c). With respect to L. potaninii, the previous August precipitation was the only factor found to positively affect its radial growth (Figure 4 d). 


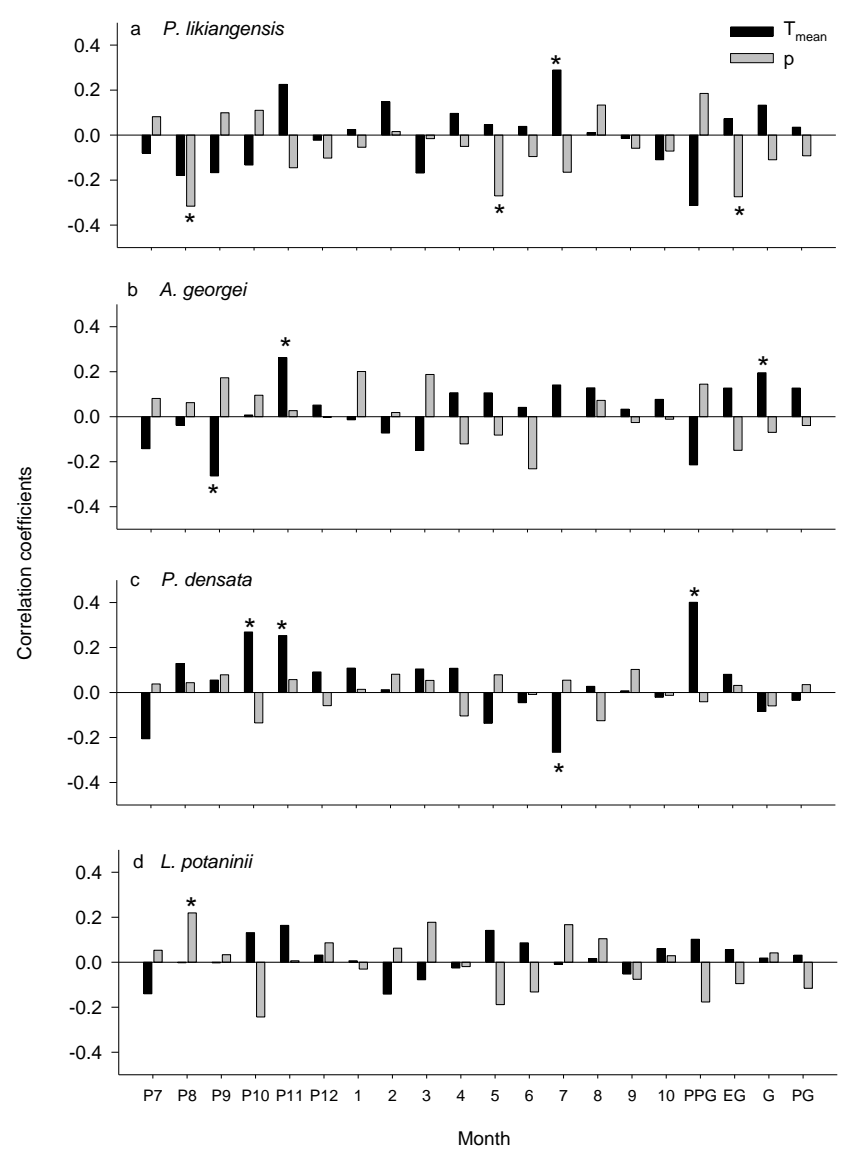

Figure 4. Correlation analyses of response function between the residual chronologies and the monthly climatic factors. ${ }^{*}$ Significant at $p<0.05$. PPG stands for previous post-growing season; EG stands for early growing season; $G$ stands for growing season; PG stands for post-growing season.

The first two ordination axes in RDA explained 32.8\% of the network's total variance (Figure 5). Axis I accounted for $21.7 \%$ and had negative loadings for all species, axis II accounted for $11.1 \%$, and had positive loadings for residual chronologies of A. georgei, P. likiangensis, and L. potaninii, and negative loadings for residual chronologies of $P$. densata. The previous July temperature was positively associated with the first axis, whereas $T_{\text {mean }}$ of the previous November and precipitation of the previous August showed a negative association. The second axis was positively associated with $T_{\text {mean }}$ of the current July and negatively with $T_{\text {mean }}$ of the previous post-growing season (September-October). The current May precipitation was associated with both axes: positive with axis I and negative with axis II.

RDA showed similar results as compared to RAF, presenting positive effects of the current July temperature on the growth of $P$. likiangensis and negative effects on $P$. densata, of the previous post-growing season temperature on $P$. densata (positive) and P. likiangensis (negative), of the previous November temperature on four species (positive), of the previous August precipitation on L. potaninii (positive) and P. likiangensis (negative), and of the current May precipitation on P. likiangensis (negative). RDA also showed significant correlations between tree growth and climatic factors that the response function did not detect. For instance, the current May precipitation and current July $T_{\text {mean }}$ had negative and positive impacts on growth of A. georgei, respectively. Previous July temperature negatively affected radial growth of the four species (Figure 5). 


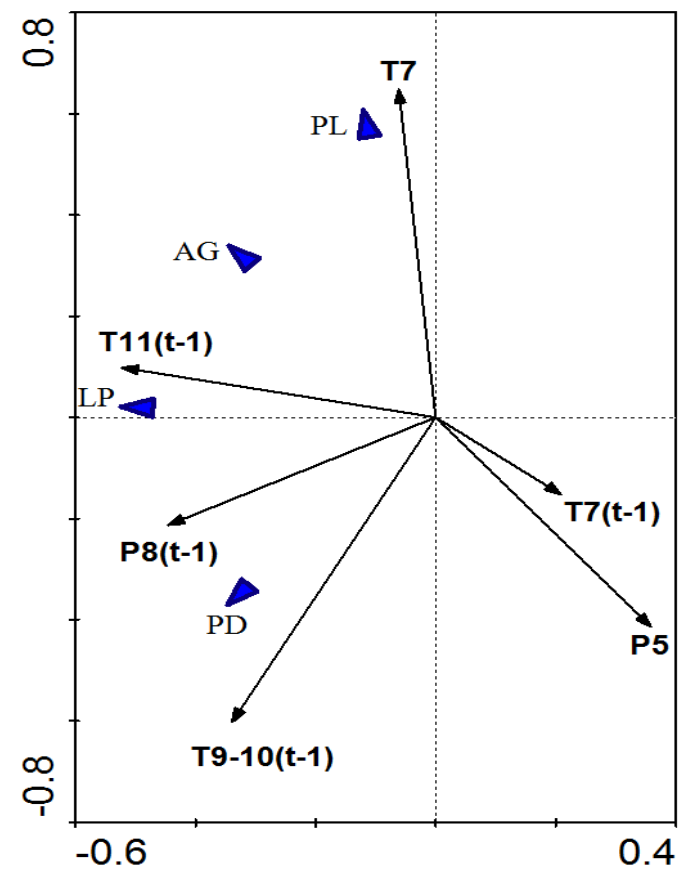

Figure 5. The redundancy analysis between two residual chronologies and the climatic factors. Only significant climate factors $(p<0.05)$ are presented. The longer the vector of the climate factor, the greater the contribution. The shorter perpendicular line between the chronology point and the climatic vector (itself, or the extension line) indicates a higher correlation between them. Chronology and vectors pointing in the same direction means a positive correlation, and vice versa. P represents precipitation; $\mathrm{T}$ represents mean temperature; $\mathrm{t}-1$ represents the previous year, the num-ber indicates the month. PL indicates the residual chronology of P. likiangensis; AG indicates the residual chronology of A. georgei; PD indicates the residual chronology of P. densata; LP indicates the residual chronology of L. potaninii.

\subsection{Dynamic Relationship between Radial Growth and Climatic Factors}

The stability between the radial growth of $P$. likiangensis and the climatic factors was high, showing a significant correlation in all tested years. Radial growth of $A$. georgei presented a stable correlation with $T_{\text {mean }}$ of the previous November and a partly significant correlation in tested years with $T_{\text {mean }}$ of the previous September. The stability between the radial growth of $P$. densata and climatic factors was high, showing a significant correlation in all tested years (except for $T_{\text {mean }}$ of the previous November). More than half of the tested years in the current August precipitation were significantly correlated with L. potaninii growth (Table 3).

Table 3. Correlation analysis with moving intervals between the residual chronologies and the monthly climatic factors. A 32-year moving window was applied.

\begin{tabular}{ccc}
\hline Tree Species & Climatic Factors & Significant Year \\
\hline \multirow{3}{*}{ P. likiangensis } & $T_{\text {mean of the current July }}$ & $1992-2011(+)$ \\
& $\begin{array}{c}\text { precipitation of the previous August } \\
\text { precipitation of the current May }\end{array}$ & $1992-2011(-)$ \\
\hline \multirow{2}{*}{ A. georgei } & $T_{\text {mean }}$ of the previous September & $1992-2011(-)$ \\
\hline \multirow{3}{*}{ P. densata } & $T_{\text {mean }}$ of the previous November & $2006-2011(-)$ \\
& $T_{\text {mean }}$ of the previous October & $1992-2011(+)$ \\
\hline L. potaninii & $T_{\text {mean }}$ of the previous November & $1992-2011(+)$ \\
& $T_{\text {mean }}$ of the current July & $2011(+)$ \\
& precipitation of the current August & $1992-2011(-)$ \\
\hline
\end{tabular}

$(-)$ indicates negative correlation; $(+)$ indicates positive correlation. 


\section{Discussion}

Our study found that both temperature and precipitation affected conifer growth in Shika Snow Mountain, which rejected the first hypothesis that low temperatures would be the only key factor influencing radial growth, suggesting the complexity of tree growth response to climate change in the area. Species presented a common response (but with consistent or inverse effects) to climate change, which supported the second hypothesis that growth sensitivity to climate was variable among species, indicating the importance of understanding species-dependent responses to climate for evaluating impacts of climate change on forest growth. Although the analyzed climate period was short, the relationship between climate variables and radial growth was stable, pointing out the reliability of our results. The study also proved that RFA and RDA complemented each other for analyzing the relationships between climate change and tree radial growth.

\subsection{Consistent Effects of Common Climatic Factors among Species}

Both RFA and RDA results showed that previous November temperature positively affected the four species' growths, suggesting its dominant role in controlling tree radial growth in Shika Snow Mountain. Severe cold combined with dry conditions in November may lead to deep soil frost which can damage roots [43,44], particularly for A. georgei, L. potaninii, and P. likiangensis, which are shallow-root species, and consequently resulting in low assimilation of nutrients in the following year. On the other hand, a warm temperature in the previous November may allow optimal growth conditions below-ground to stimulate the radial growth of the next year. Positive influences of the previous November temperatures on the radial growth of different conifers have also been found at nearby sites (Baima Snow Mountain and Bitahai Nature Reserve) and in subalpine mountain zones in North America for Sargent's spruce (Picea brachytyla (Franch.) E.Pritz.), Subalpine fir (Abies lasiocarpa (Hook.) Nutt.), Engelmann spruce (Picea engelmannii Parry ex Engelm), and Alpine Larch (Larix lyallii Parl.) [22,45].

Current May precipitation was found to negatively affect radial growth of A. georgei and P. likiangensis. Rain is typically accompanied with low temperatures and cloudy conditions, which can reduce the photosynthesis rate and photosynthetic capture, and slow soil thawing, which can weaken root activity and may trigger the onset of photosynthesis [46,47]. In addition, more precipitation during the early growing season can create waterlogged conditions associated with a decrease in soil oxygen content and an increase in carbon dioxide concentration, resulting in anaerobic respiration of the root, excessive consumption of photosynthates and, consequently, inhibiting tree radial growth [48]. Negative influences of the current early growing season precipitation on radial growth have also been found for P. brachytyla in Potatso National Park (20 km away from our site) [29].

In addition, the previous July temperature had negative impacts on the growth of all four species. It is likely that a previous hot summer could enhance stand evapotranspiration and thereby cause water deficits [49]. This water-stress effect was also indicated by a positive effect of previous August precipitation on radial growth of A. georgei, L. potaninii, and P. densata. Previous summer moisture conditions could affect the size of buds within the leaf area for photosynthetic efficiency of the current year, and thereby suitable previous summer conditions allowed optional growth of the following year [50]. The previous summer water-stress effect on tree radial growth was also reported for P. likiangensis in Small Zhongdian (100 km away from our site) [51] and other subalpine conifers $[22,24]$.

\subsection{Divergent Effects of Common Climatic Factors among Species}

Temperatures of the previous post-growing season (September-October) were found to be a critical climatic factor influencing tree growth in the area, showing positive effects on P. densata and negative effects on $P$. likiangensis, respectively. This may reflect differences of physiological responses in daytime and nighttime between the two species. High daily temperatures can raise photosynthesis 
rates and, therefore, produce more carbohydrates for radial growth [52], but increases in nighttime temperature could enhance tree respiration, thus, leading to the consumption of the carbohydrates that were reserved for the following year's growth [49].

Our results also revealed that the current summer moisture condition was important for tree growth in the area. The temperature of the current growing season (June-August), especially for July temperature, showed positive effects on the growth of A. georgei and P. likiangensis, and negative effects on $P$. densata. This moisture stress effect was also confirmed by positive influences of the current August precipitation on radial growth of $A$. georgei and P. likiangensis. The inverse growth response was mainly due to the habitat difference. High temperatures during the growing season can improve the photosynthesis rate and increase the pool of stored carbohydrates for tree growth [53], however, higher temperatures could cause higher stand respiration and evaporation, consequently resulting in water deficits which may inhibit radial growth [54]. P. likiangensis and A. georgei are shade-tolerant species, growing in the shaded and half-shaded slopes with less radiation and evaporation and, therefore, higher amounts of moisture are available for tree growth. The positive influence of the current July temperatures on radial growth of P. likiangensis and A. georgei was also reported in the Southeastern Tibetan Plateau (the same region of our study area) [33,55]. In contrast, $P$. densata is a shade-intolerant species, typically distributed in sunny and half-sunny slopes with strong solar radiation and high evaporation; thus, high summer temperatures could cause soil moisture stress and growth was limited.

\subsection{Prediction of Future Climate Change on Tree Radial Growth}

Global warming has become an indisputable fact since the 20th century. The global mean temperature rose $0.72{ }^{\circ} \mathrm{C}\left(0.49\right.$ to $\left.0.89^{\circ} \mathrm{C}\right)$ from 1901 to 2012 , and the warming of the second half of the 20th century was more obvious with the increase of $0.12{ }^{\circ} \mathrm{C}\left(0.08\right.$ to $\left.0.14{ }^{\circ} \mathrm{C}\right)$ per decade from 1951 to 2012 [56]. Relative to temperature, the precipitation since 1901 has only slightly increased [57]. In Southwest China, compared with the data in 1961-1990, the mean temperature in spring, summer, autumn, and winter are projected to increase $2.6^{\circ} \mathrm{C}, 3.1^{\circ} \mathrm{C}, 2.7^{\circ} \mathrm{C}$, and $3.1{ }^{\circ} \mathrm{C}$ in $2071-2100$, and precipitation in spring, summer, autumn, and winter will relatively increase $8 \%, 7 \%, 6 \%$, and $8 \%$ (under the Special Report on Emissions Scenarios (SRES) B2 scenario) [58].

Based on the understanding of the growth responses of the four species to climate (see above) and the prediction of future temperature and precipitation, our study may allow us to assess potential changes in tree and forest growth in this area. We focus more on temperature influences on tree growth than precipitation since predictions of temperature from different models might be very similar, while precipitation would be different. In general, November temperature, summer moisture conditions, autumn temperature, and May precipitation mainly influenced the radial growth of the four species. All four species might benefit from warming in November to enhance their radial growth. The effects of summer moisture conditions on tree growth were difficult to predict, since both temperature and precipitation were forecasted to increase. Nevertheless, the increase in summer temperature may put more evaporative stress on the two shade-intolerant species due to their higher stand evaporation rate and the requirement for water in physiology. If water compensation is insufficient, warmer summer seasons in coming decades may limit radial growth of the four species, particularly for P. densata and L. potaninii. Warming autumn seasons will probably promote the growth of the two shade-intolerant conifers and inhibit the growth of the two shade-tolerant conifers. Radial growth of the four species might be decreasing due to increases in future May precipitation. In accordance with the above description, we may predict how species respond in the context of future climate change, but it is difficult to predict the pattern of forest growth since future climate change might cause both increases and decreases for those species (the main component of forests). In addition, the future forest growth would be strongly modified by indirect influences of climate change, such as extreme climate events, fire and wind disturbances, and insect outbreak. Therefore, prediction in forest growth is complex and needs comprehensive consideration. 


\section{Conclusions}

In this paper, we compared the growth response of four species to temperatures and precipitation at upper distributional limits in Shika Snow Mountain. We found that temperature from September to November in the previous year, current summer moisture condition, and current May precipitation were important factors affecting the radial growth of the dominant conifers in the study area. The growth sensitivity to climate conditions was variable among species, this was mainly due to their different physiological adaptations, growth strategies, and site conditions.

Acknowledgments: We gratefully acknowledge the field assistance of Guanglei Chen, Zhenya Liu, and Zhibao Wang. We thank Quanquan Wang with help in improving the quality of the figures. This research was supported by the National Natural Science Foundation of China (31600395), the Key Program of the Educational Department of Yunnan Province (2015Z136), and the Plateau Wetlands Science Innovation Team of Yunnan Province (2012HC007).

Author Contributions: Y.Z. and W.Z. conceived the study and wrote the paper. D.Y. and M.S. designed the study and performed the experiment. H.W. and K.T. analyzed the data. D.X. contributed materials and analysis tools.

Conflicts of Interest: The authors declare no conflict of interest.

\section{References}

1. Boisvenue, C.; Running, S.W. Impacts of climate change on natural forest productivity: Evidence since the middle of the 20th century. Glob. Chang. Biol. 2006, 12, 862-882. [CrossRef]

2. Van Mantgem, P.J.; Stephenson, N.L.; Byrne, J.C.; Daniels, L.D.; Franklin, J.F.; Fulé, P.Z.; Harmon, M.K.; Larson, A.J.; Smith, J.M.; Taylor, A.H.; et al. Widespread increase of tree mortality rates in the western United States. Science 2009, 323, 521-524. [CrossRef] [PubMed]

3. Tao, J.; Chen, Y.F.; He, D.K.; Ding, C.Z. Relationships between Climate and growth of Gymnocypris selincuoensis in the Tibetan Plateau. Ecol. Evol. 2015, 5, 1693-1701. [CrossRef] [PubMed]

4. Fritts, H.C. Tree Rings and Climate; Academic Press: New York, NY, USA, 1976.

5. Zhang, Q.B.; Cheng, G.D.; Yao, T.D.; Kang, X.C.; Huang, J.G. A 2326-year tree-ring record of climate variability on the northeastern Qinghai-Tibetan Plateau. Geophys. Res. Lett. 2003, 30. [CrossRef]

6. Shao, X.; Xu, Y.; Yin, Z.Y.; Liang, E.; Zhu, H.; Wang, S. Climatic implications of a 3585-year tree-ring width chronology from the northeastern Qinghai-Tibetan Plateau. Quat. Sci. Rev. 2010, 29, 2111-2122. [CrossRef]

7. Liang, E.Y.; Shao, X.M.; Eckstein, D.; Huang, L.; Liu, X.H. Topography- and Species-dependent growth responses of Sabina przewalskii and Picea crassifolia to climate on the northeast Tibetan Plateau. For. Ecol. Manag. 2006, 236, 268-277. [CrossRef]

8. Cook, E.R.; Glitzenstein, J.S.; Krusic, P.J.; Harcombe, P.A. Identifying functional groups of trees in west Gulf Coast forests (USA): A tree-ring approach. Ecol. Appl. 2001, 11, 883-903. [CrossRef]

9. Friedrichs, D.A.; Trouet, V.; Büntgen, U.; Frank, D.C.; Esper, J.; Neuwirth, B.; Löffler, J. Species-specific climate sensitivity of tree growth in Central-West Germany. Trees 2009, 23, 729-739. [CrossRef]

10. Yu, D.P.; Wang, Q.W.; Wang, Y.; Zhou, W.M.; Ding, H.; Fang, X.M.; Jiang, S.W.; Dai, L.M. Climatic effects on radial growth of major tree species on Changbai Mountain. Ann. For. Sci. 2011, 68, 921-933. [CrossRef]

11. Frits, H.C.; Smith, D.G.; Cardis, J.W.; Budelsky, C.A. Tree-ring characteristics along a vegetation gradient in northern Arizona. Ecology 1965, 46, 393-401. [CrossRef]

12. Takahashi, K.; Azuma, H.; Yasue, K. Effects of climate on the radial growth of tree species in the upper and lower distribution limits of an altitudinal ecotone on Mount Norikura, central Japan. Ecol. Res. 2003, 18, 549-558. [CrossRef]

13. Zhang, Y.; Bergeron, Y.; Gao, L.S.; Zhao, X.H.; Wang, X.M.; Drobyshev, I. Tree growth and regeneration dynamics at a mountain ecotone on Changbai Mountain, northeastern China: Which factors control species distributions? Écoscience 2014, 21, 387-404. [CrossRef]

14. Zhang, Y.; Bergeron, Y.; Zhao, X.H.; Drobyshev, I. Stand history is more important than climate in controlling red maple (Acer rubrum L.) growth at its northern distribution limit in western Quebec, Canada. J. Plant Ecol. 2015, 8, 368-379. [CrossRef]

15. Smith, W.K.; Germino, M.J.; Johnson, D.M.; Reinhardt, K. The altitude of alpine treeline: A bellwether of climate change effects. Bot. Rev. 2009, 75, 163-190. [CrossRef] 
16. Payette, S.; Delwalde, A.; Morneau, C.; Lavole, C. Patterns of tree stem decline along a snow-drift gradient at treeline: A case study using stem analysis. Can. J. Bot. 1996, 74, 1671-1683. [CrossRef]

17. Zhang, W.T.; Jiang, Y.; Dong, M.Y.; Kang, M.Y.; Yang, H.C. Relationship between the radial growth of picea meyeri and climate along elevations of the Luyashan Mountain in North-Central China. For. Ecol. Manag. 2012, 265, 142-149. [CrossRef]

18. Leal, S.; Melvin, T.; Grabner, M.; Wimmer, R.; Briffa, K. Tree-ring growth variability in the Austrian Alps: The influence of site, altitude, tree species and climate. Boreas 2007, 36, 426-440. [CrossRef]

19. Liang, E.; Wang, Y.; Xu, Y.; Liu, B.; Shao, X. Growth variation in Abies georgei var. smithii along altitudinal gradients in the Sygera Mountains, southeastern Tibetan Plateau. Trees 2010, 24, 363-373.

20. Shi, J.F.; Li, J.B.; Cook, E.R.; Zhang, X.Y.; Lu, H.Y. Growth response of Pinus tabulaeformis to climate along an elevation gradient in the eastern Qinling Mountains, central China. Clim. Res. 2012, 53, 157-167. [CrossRef]

21. Liu, X.D.; Chen, B.D. Climatic warming in the Tibetan Plateau during recent decades. Int. J. Climatol. 2000, 20, 1729-1742. [CrossRef]

22. Fan, Z.X.; Bräuning, A.; Cao, K.F. Annual temperature reconstruction in the central Hengduan Mountains, China, as deduced from tree rings. Dendrochronologia 2008, 26, 97-107. [CrossRef]

23. Fan, Z.X.; Bräuning, A.; Cao, K.F. Tree-ring based drought reconstruction in the central Hengduan Mountains region (China) since A.D. 1655. Int. J. Climatol. 2008, 28, 1879-1887. [CrossRef]

24. Fan, Z.X.; Bräuning, A.; Yang, B.; Cao, K.F. Tree ring density-based summer temperature reconstruction for the central Hengduan Mountains in southern China. Glob. Planet. Chang. 2009, 65, 1-11. [CrossRef]

25. Bi, Y.F.; Xu, J.C.; Gebrekirstos, A.; Guo, L.; Zhao, M.X.; Liang, E.Y.; Yang, X.F. Assessing drought variability since 1650 AD from tree-rings on the Jade Dragon Snow Mountain, southwest China. Int. J. Climatol. 2015, 35, 4057-4065. [CrossRef]

26. Guo, G.A.; Li, Z.S.; Zhang, Q.B.; Ma, K.P.; Mu, C.L. Dendroclimatological studies of Picea likiangensis and Tsuga dumosa in Lijiang, China. IAWA J. 2009, 30, 435-441. [CrossRef]

27. Li, Z.S.; Zhang, Q.B.; Ma, K.P. Tree-ring reconstruction of summer temperature for A.D. 1475-2003 in the central Hengduan Mountains, Northwestern Yunnan, China. Clim. Chang. 2002, 110, 455-467. [CrossRef]

28. Zhang, W.G.; Xiao, D.R.; Tian, K.; Chen, G.L.; He, R.H.; Zhang, Y. Response of radial growth of three conifer species to climate at their respective upper distributional limits on Yulong Snow Mountain. Acta Ecol. Sin. 2017, 37, 3796-3804. (In Chinese) [CrossRef]

29. Yu, J.L.; Zhang, W.G.; Tian, K.; Song, W.H.; Li, Q.P.; Yang, R.; Zhang, Y. Response of radial growth of three conifer trees to climate change at their upper distribution limits in Potatso National Park, Shangri-La, southwestern China. J. Beijing For. Univ. 2017, 39, 43-51. (In Chinese)

30. Stokes, M.A.; Smiley, T.L. An Introduction to Tree-Ring Dating; University of Chicago Press: Chicago, IL, USA, 1968.

31. Larsson, L.A. CDendro v. 7.3. Cybis Elektronik \& Data AB; Saltsjöbaden, Sweden, 2010. Available online: http:/ / www.cybis.se/indexe.htm (accessed on 11 July 2017).

32. Holmes, R.L. Computer-assisted quality control in tree-ring dating and measurement. Tree-Ring Bull. 1983, 43, 69-75.

33. Liang, E.Y.; Shao, X.M.; Xu, Y. Tree-ring evidence of recent abnormal warming on the southeast Tibetan Plateau. Theor. Appl. Climatol. 2009, 98, 9-18. [CrossRef]

34. Cook, E.R.; Holmes, R.L. Users Manual for Program ARSTAN; Laboratory of Tree-Ring Research, University of Arizona: Tucson, AZ, USA, 1986.

35. Kendall, M.G.; Gibbons, J.D. Rank Correlation Methods, 5th ed.; Edward Arnold: London, UK, 1990.

36. Biondi, F.; Waikul, K. DENDROCLIM2002: A C++ program for statistical calibration of climate signals in tree-ring chronologies. Comput. Geosci. 2004, 30, 303-311. [CrossRef]

37. Fritts, H.C.; Blasing, T.J.; Hayden, B.P.; Kutzbach, J.E. Multivariate techniques for specifying tree-growth and climate relationships ad for reconstructing anomalies in paleoclimate. J. Appl. Meteorol. Climatol. 1971, 10, 845-864. [CrossRef]

38. Legendre, P.; Legendre, L. Numerical Ecology; Elsevier Scientific: New York, NY, USA, 1998.

39. Ter Braak, C.J.F.; Smilauer, P. CANOCO Reference Manual and User's Guide to Canoco for Windows-Software for Canonical Community Ordination, version 4; Microcomputer Power: Ithaca, NY, USA, 1998.

40. Ter Braak, C.J.F.; Smilauer, P. CANOCO Reference Manual and CanoDraw for Windows User's Guide: Software for Canonical Community Ordination, version 4.5; Microcomputer Power: Ithaca, NY, USA, 2002. 
41. Wigley, T.M.L.; Briffa, K.R.; Jones, P.D. On the average value of correlated time series with application in dendroclimatology and hydrometeorology. J. Appl. Meteorol. Climatol. 1984, 23, 201-213. [CrossRef]

42. Briffa, K.R. Interpreting high-resolution proxy climate data-The example of dendroclimatology. In Von Analysis of Climate Variability: Applications of Statistical Techniques; Storch, H., Navarra, A., Eds.; Springer: Berlin, Germany, 1995; pp. 77-94.

43. Vogt, K.A.; Edmonds, R.L.; Grier, C.C.; Piper, S.R. Seasonal changes in mycorrhizal and fibrous-textured root biomass in 23- and 180-year-old Pacific silver fir stands in western Washington. Can. J. For. Res. 1980, 10, 523-529. [CrossRef]

44. Neuner, G. Frost resistance at the upper timberline. In Trees at Their Upper Limit-Treelife Limitation at the Alpine Timberline; Wieser, G., Tausz, M., Eds.; Springer: Dordrecht, The Netherlands, 2007; pp. 171-180.

45. Peterson, D.W.; Peterson, D.L. Effects of climate on the radial growth of subalpine conifers in the North Cascade Mountains. Can. J. For. Res. 1994, 24, 1921-1932. [CrossRef]

46. Fan, Z.X.; Bräuning, A.; Cao, K.F.; Zhu, S.D. Growth-climate responses of high-elevation conifers in the central Hengduan Mountains, southwestern China. For. Ecol. Manag. 2009, 258, 306-313. [CrossRef]

47. Goodine, G.K.; Lavigne, M.B.; Krasowski, M.J. Springtime resumption of photosynthesis in balsam fir (Abies balsamea). Tree Physiol. 2008, 28, 1069-1076. [CrossRef] [PubMed]

48. Gao, L.S.; Wang, X.M.; Zhao, X.H. Response of Pinus koraiensis and Picea jezoensis var. komarovii to climate in the transition zone of Changbai Mountain, China. Chin. J. Plant Ecol. 2011, 35, 27-34. (In Chinese)

49. Huang, J.G.; Tardif, J.; Bergeron, Y.; Denneler, B.; Berninger, F.; Girardin, M.P. Radial growth response of four dominant boreal tree species to climate along a latitudinal gradient in the eastern Canadian boreal forest. Glob. Chang. Biol. 2010, 16, 711-731. [CrossRef]

50. Dang, Q.L.; Margolis, H.A.; Collatz, G.J. Parameterization and testing of a coupled photosynthesis-stomatal conductance model for boreal trees. Tree Physiol. 1998, 18, 141-153. [CrossRef] [PubMed]

51. Zhao, Z.J.; Tan, L.Y.; Kang, D.W.; Liu, Q.J.; Li, J.Q. Response of Picea likiangensis radial growth to climate change in the Small Zhongdian area of Yunnan Province, Southwest China. Chin. J. Appl. Ecol. 2012, 23, 603-609. (In Chinese)

52. Dang, H.S.; Zhang, Y.J.; Zhang, K.R.; Jiang, M.X.; Zhang, Q.F. Climate-growth relationships of subalpine fir (Abies fragesii) across the altitudinal range in the Shennongjia Mountains, central China. Clim. Chang. 2013, 117, 903-917. [CrossRef]

53. Wang, X.; Zhao, X.; Gao, L. Climatic response of Betula ermanii along an altitudinal gradient in the northern slope of Changbai Mountain, China. Dendrobiol. 2013, 70, 99-107. [CrossRef]

54. Shi, X.H.; Qin, N.S.; Zhu, H.F.; Shao, X.M.; Wang, Q.C.; Zhu, X.D. May-June mean maximum temperature change during 1360-2005 as reconstructed by tree rings of Sabina Tibetica in Zaduo, Qinghai Province. Chin. Sci. Bull. 2010, 26, 3023-3029. [CrossRef]

55. Liang, E.Y.; Shao, X.M.; Qin, N.S. Tree-ring based summer temperature reconstruction for the source region of the Yangtze River on the Tibetan Plateau. Glob. Planet. Chang. 2008, 61, 313-320. [CrossRef]

56. Intergovernmental Panel on Climate Change (IPCC). Contribution of Working Group I to the Fifth Assessment Report of the Intergovernmental Panel on Climate Change, 2013; Cambridge University Press: Cambridge, UK; New York, NY, USA, 2013.

57. Intergovernmental Panel on Climate Change (IPCC). Contribution of Working Group II to the Fourth Assessment Report of the Intergovernmental Panel on Climate Change, 2007; Cambridge University Press: London, UK, 2007.

58. Xu, Y.L.; Huang, X.Y.; Zhang, Y.; Lin, W.T.; Lin, E.D. Statistical analyses of climate change scenarios over China in the 21st century. Adv. Clim. Chang. Res. 2005, 2, 50-53.

(C) 2017 by the authors. Licensee MDPI, Basel, Switzerland. This article is an open access article distributed under the terms and conditions of the Creative Commons Attribution (CC BY) license (http://creativecommons.org/licenses/by/4.0/). 